\title{
Twenty-five years post-treatment conifer responses to silviculture on a Kalmia-dominated site in eastern Canada
}

\author{
by Nelson Thiffault ${ }^{1}$, Brian D. Titus ${ }^{2}$ and Basil English ${ }^{3}$
}

\begin{abstract}
Research has demonstrated the potential of soil scarification, fertilization, and herbicide application to improve conifer seedling establishment and early growth. However, tree responses to and interactions among silvicultural treatments vary, making it difficult to predict mid- and long-term impacts of silviculture on stand productivity. We thus evaluated the 25year effects of scarification and herbicide-fertilization combinations on black spruce (Picea mariana), jack pine (Pinus banksiana) and tamarack (Larix laricina) planted on a Kalmia angustifolia-dominated site. Our results show that the effects of scarification and herbicide-fertilization combinations diverged among species. Black spruce was the most responsive species to scarification for height and diameter at breast height. The combination of herbicide and fertilization treatments still had significantly positive effects on the long-term height and diameter growth of all species. Silvicultural treatments resulted in significant reductions in rotation length (based on height) when compared to height in nontreated-plots, depending on the species; reductions in years to attain a given height were greater for black spruce than for the other species. Our results illustrate the need to take species autecology into account when predicting productivity gains associated with early silviculture, and to provide managers with specific guidelines for the reforestation of ericaceous-dominated sites in Canadian boreal ecosystems.
\end{abstract}

\section{Keywords}

Kalmia angustifolia, vegetation management, scarification, autecology, herbicide, fertilization, black spruce, jack pine, tamarack

\section{RÉSUMÉ}

La recherche scientifique a déjà montré que le scarifiage, la fertilisation et les épandages d'herbicides pouvaient améliorer l'établissement et la croissance initiale des semis de conifères. Cependant, la réaction des arbres aux interventions sylvicoles et leurs interactions viennent compliquer la prédiction des effets à moyen et long termes des interventions sylvicoles sur la productivité à l'échelle du peuplement. Ainsi, nous avons voulu évaluer après 25 ans l'effet de du scarifiage et de diverses combinaisons d'herbicides-fertilisation sur lépinette noire (Picea mariana), le pin gris (Pinus banksiana) et le mélèze laricin (Larix laricina) en plantation sur une station à dominance de Kalmia angustifolia. Nous avons observé que le scarifiage et différentes combinaisons d'herbicides-fertilisation avaient des effets différents selon les essences. Cest lépinette noire qui a connu la réponse la plus importante au scarifiage, tant en hauteur qu’en diamètre. Les combinaisons de traitements avec des herbicides et des engrais ont amélioré de façon significative la croissance à long terme en hauteur et en diamètre de toutes les essences. Les traitements sylvicoles ont réduit de façon variable la révolution (basée sur la hauteur) par rapport aux placettes non traitées, cette réduction variant suivant les essences; la réduction a été plus importante pour l'épinette noire que pour les autres essences. Nos résultats indiquent l'importance de tenir compte de l’autécologie pour prévoir les gains de productivité associés à des traitements sylvicoles en bas âges et pour bien guider les aménagistes dans le reboisement des stations à dominance déricacées dans les écosystèmes de la forêt boréale au Canada.

Mots-clés : Kalmia angustifolia, gestion de la végétation, scarifiage, autécologie, herbicide, fertilisation, épinette noire, pin gris, mélèze laricin

\footnotetext{
${ }^{1}$ Direction de la recherche forestière, Min. des Forêts, de la Faune et des Parcs du Québec, Québec G1P 3W8, and Centre d'Étude de la Forêt (CEF). Corresponding author. Email: nelson.thiffault@mffp.gouv.qc.ca

${ }^{2}$ Natural Resources Canada, Pacific Forestry Centre, 506 West Burnside Rd., Victoria, British Columbia V8Z 1 M5.

${ }^{3}$ Silviculture Section, Forest Service of Newfoundland and Labrador, P.O. Box 2006, Corner Brook, Newfoundland A2H $6 \mathrm{~J} 8$.
} 


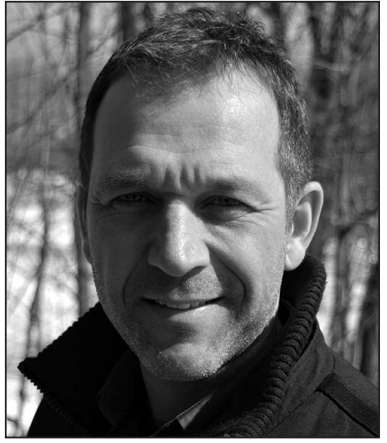

Nelson Thiffault

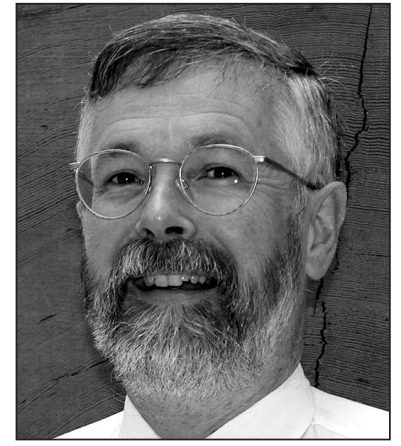

Brian D. Titus



Basil English direct influence on inter-specific competition (Walstad and Kuch 1987) by typically increasing the levels of environmental resources (Brand 1991), and conifers show significant increases in growth in most ecosystems when sites are treated with chemical herbicides (see review by Wagner et al. 2005).

Crop-species responses to silvicultural treatments vary, however, depending on key functional traits such as shadetolerance or nutrient require-

\section{Introduction}

Forest growth in boreal ecosystems is constrained by short growing seasons, cold air temperatures, cold soils, and slow decomposition rates (Saucier et al. 2015). Successful stand development following harvesting or natural disturbances can be further limited after site encroachment by exotic or native understory plants (Nilsson and Wardle 2005, De Grandpré et al. 2014). Understory species can impede tree regeneration (Royo and Carson 2006) with significant impacts on stand recruitment and structure (e.g., Lorimer et al. 1994). In particular, species of the Ericaceae and Empatraceae families, (which are both members of the order Ericales), can negatively affect regeneration establishment and growth, influence belowground properties, and ultimately modify forest succession (Mallik 2003); where this occurs, reforestation efforts can be challenging. Gaultheria shallon Pursh on the west coast of Canada (Prescott and Sajedi 2008), Kalmia angustifolia L. (hereafter referred to as Kalmia) (Titus et al. 1995) and Rhododendron groenlandicum (Oeder) Kron and Judd (Thiffault et al. 2012a) in eastern North America, Calluna vulgaris (L.) Hull in northern Great Britain (Weatherell 1953), and Empetrum hermaphroditum Hagerup in Scandinavia (Zackrisson et al. 1997) are examples of ericaceous and related species that can affect forest productivity by inducing chlorosis and stunted growth ("growth check") of naturally established and planted conifers (de Montigny and Weetman 1990, Thiffault et al. 2013) in northern temperate and boreal forests.

Past research has demonstrated the potential of soil scarification (e.g., Richardson 1979, Prévost and Dumais 2003), fertilization (e.g., Holmes and Cousins 1960, Taylor and Tabbush 1990, Blevins et al. 2006), and herbicide application (LeBel et al. 2008) to improve conifer seedling establishment and early growth. Soil scarification in boreal ecosystems disturbs the thick organic layer and exposes the mineral soil, thus increasing root zone temperatures, favouring better access to soil water, stimulating decomposition, and creating competition-free microsites (Örlander et al. 1990, Prévost 1992). Scarification ultimately reduces the planting stress of seedlings and results in increased early seedling survival and growth (Thiffault et al. 2005). Fertilization compensates for the low nutrient availability inherent to boreal sites by increasing availability of key elements (mainly $\mathrm{N}$ and $\mathrm{P}$ ) to planted conifers (Brais et al. 2015), which usually increases growth significantly (Sloan and Jacobs 2013, Moulinier et al. 2015). Finally, vegetation management with herbicides has a ments (Périé and Munson 2000, Wagner and Robinson 2006, Kranabetter et al. 2017). For example, we recently observed that fast-growing, light-demanding jack pine (Pinus banksiana Lamb.) exhibited a non-linear growth response to Kalmia proximity as influenced by soil scarification, while the slow-growing, shade-tolerant black spruce (Picea mariana (Mill.) BSP) responded linearly to this variable (Thiffault et al. 2012b). Silvicultural treatments can also interact with each other, leading to multiplicative rather than additive responses of planted trees; for example, Nilsson and Örlander (2003) reported that fertilization significantly increased Norway spruce growth in the short- term when combined with herbicide application, but fertilization effects were not significant when competing vegetation was left untouched. Interactions between planted species and silvicultural treatments, and among silvicultural treatments, make it difficult to predict mid- and long-term impacts of reforestation strategies on stand productivity (Mason 1992), and there is thus a need to acquire and analyse long-term empirical data from silvicultural trials to inform the management decisions required for sustainable production of ecosystem services, including wood supply. Moreover, although short-term effects of scarification, fertilization and herbicide treatments have been demonstrated in many boreal conditions, long-term benefits of these treatments have yet to be assessed for sites dominated by ericaceous species in eastern North America.

Our overall objective was to evaluate the long-term effects of scarification and combinations of herbicides and fertilization on the growth of planted black spruce, jack pine and tamarack (Larix laricina (Du Roi) K. Koch) on a Kalmia dominated site in central Newfoundland, Canada. Kalmia is frequently found in the understory of black spruce-dominated forests, and can proliferate rapidly after canopy opening resulting from harvesting, fire or insect outbreak (Titus et al. 1995, Thiffault et al. 2013). We used data from a 25 -year-old silvicultural trial that included combinations of planted species and treatments that can reasonably be used operationally for the management of ericaceous-dominated sites in boreal North America. Our specific objectives were to: (1) evaluate treatments and species main and interaction effects on tree height, diameter at breast height and estimated tree volume 25 years after planting; and, (2) compare the increase in time required for different species under control conditions to attain a height similar to that of trees 25 years after planting which have been silviculturally treated (i.e., 
increased rotation length, making the conservative assumption that growth rates are similar once trees in control plots reach the 25-year height of trees in silviculturally treated plots). Based on results obtained 15 years after treatment (Thiffault et al. 2010), we expected to find significant interactions between silvicultural treatments and planted species. We also posited that the increase in time for trees in control plots to reach a height that was comparable to that after 25 years in treated plots would be species-specific (i.e., more important for slow-growing black spruce than for fast-growing jack pine and tamarack).

\section{Materials and Methods \\ Site description}

This study is based on data from an experimental field trial established near the town of Botwood in north-central Newfoundland (lat. $49^{\circ} 07^{\prime} \mathrm{N}$; long. $55^{\circ} 26^{\prime} \mathrm{W}$ ). The region has a humid continental climate with cool summers and no dry season. The mean annual temperature is $4.7^{\circ} \mathrm{C}$, with an annual frost-free period lasting 103 days, and annual average precipitation is $1140 \mathrm{~mm}$ of which $26 \%$ falls as snow (1981-2010 climate normal; Environment Canada 2010). The soil in the experimental area is an orthic humo-ferric podzol (Soil Classification Working Group 1998) that formed from a uniform glaciofluvial terrace deposit which enables good drainage. Texture of the mineral horizons ranges from silt loam to very fine sandy loam. The soil is covered by a mor humus $9-12 \mathrm{~cm}$ thick. The Damman forest type is Pleurozium Balsam Fir, with some areas transitional to Hylocomium Balsam Fir (Meades and Moores 1994). Black spruce dominated the previous stand, which was commercially thinned in 1973-1974 before burning in a wildfire in 1979 at age 70- to 75 -years, after which it was salvage cut in 1982. The management history contributed to Kalmia increasing in cover and spreading until it dominated the site, with Alnus viridis subsp. crispa (Ait.) Turrill (also known as A. crispa (Ait.) Pursh), Amelanchier bartramiana (Taush) Roemer, Betula papyrifera Marsh., Prunus pensylvanica L.f., Salix spp., Viburnum nudum var. cassinoides (L.) Torrey \& Gray (also known as $V$. cassinoides L.), and Vaccinium spp. as the main companion species.

\section{Experimental design and treatments}

In 1989 we established 36 experimental units (2 scarification levels $\times 6$ factorial herbicide-fertilizer combinations $\times 3$ conifer species) combined in a complete block split-split-plot design with four replicates $\sim 1.35$ ha each (Fig. 1; see Thiffault et al. 2010 for details). In summary, we split each experimental block in half to create two main plots, one of which was randomly selected for soil scarification (S1) in the fall of 1989 with a TTS passive disk trencher. The other main plot of each block was left unscarified (S0). We divided each main plot into six $30-\mathrm{m} \times 30-\mathrm{m}$ subplots with a $5-\mathrm{m}$ buffer between them; we considered only four subplots in the actual study because the micronutrients in an NPK + micronutrient treatment did not increase growth compared to NPK alone, and would not be operationally feasible because of additional application costs. We randomly assigned one of four factorial combinations of a herbicide $(\mathrm{H})$-fertilizer $(\mathrm{F})$ treatment to each of the four subplots $(\mathrm{HOF} 0=$ no herbicide, no fertilization; $\mathrm{HOF} 1$ = no herbicide, with fertilization; H1F0 = with herbicide, no fertilization; H1F1 = with herbicide, with fertilization). The herbicide treatment consisted of the application of hexazinone (Velpar $\mathrm{L}^{\circ}$ ) at $18{\mathrm{~L} \times h a^{-1}}^{-1} 4.32 \mathrm{~kg}$ active ingredient $\left.\times \mathrm{ha}^{-1}\right)$ in $300 \mathrm{~L} \times \mathrm{ha}^{-1}$ water applied pre-bud break in late

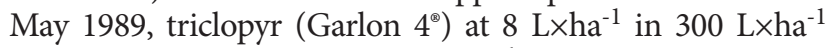
water (3.84 kg active ingredient $\times \mathrm{ha}^{-1}$ ) applied just after full leaf extension in mid-July 1989, and spot application of

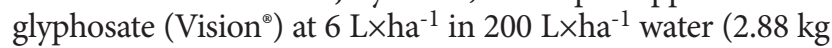
active ingredient $\left.\times \mathrm{ha}^{-1}\right)$ in mid-September 1989 and late June 1992 , with planted conifers covered with plastic bags for protection. (This treatment was used to enhance eradication in the expectation that the efficacy of operational treatments would increase with experience.) Fertilization consisted of a hand-broadcast application at the time of planting of 15-15-15 NPK as urea, triple super phosphate, and muriate of potash at rates of 150,138 , and $120 \mathrm{~kg} \times \mathrm{ha}^{-1}$ of N, P, and $\mathrm{K}$, respectively. We further split the subplots into three $10 \mathrm{~m} \times 30$ $\mathrm{m}$ sub-subplots and randomly assigned them to be planted in June-July 1990 with either black spruce (seed source from Carmanville, NL), jack pine (seed source from Chibougamau, QC), or tamarack (seed source from Saguenay, QC). Seedlings were produced in $73-\mathrm{cm}^{3}$ containers and planted at a 1-m spacing along rows $2-\mathrm{m}$ apart, resulting in $\sim 150$ seedlings per sub-subplot, which were thinned down to $\sim 75$ seedlings per sub-subplot over the first five years of the study. In scarified plots, we planted the seedlings in the hinge position (the trench-berm interface; Örlander et al. 1990).

\section{Tree measurements}

We measured all living trees for total height $(\mathrm{m})$ at the end of their $15^{\text {th }}$ growing season (Aug.-Sept. 2004), and an experimental unit contained between 23 and 50 living trees. We revisited the study site 25 full growing seasons after planting (Nov. 2014) to measure diameter at breast height (dbh; $\mathrm{cm}$ ) and total height $(\mathrm{m})$ of 14 seedlings in each sub-subplot. We used the first rows of planted trees in all directions as buffers to avoid edge effects and only measured seedlings in the central rows (Fig. 1), systematically starting with the second tree of the second row in the south-west corner of each sub-subplot. Volume tables for the studied species (e.g., Perron 2003) are limited to trees with $\mathrm{dbh} \geq 9.1 \mathrm{~cm}$ and hence could not be applied in our study because most trees had yet to reach this minimum diameter threshold (see Results). We therefore used height and dbh data to calculate stem biomass using the species-specific equations of Lambert et al. (2005) and converted the results into an estimated stem volume using species-specific basic density values (dry biomass/green volume; Jessome 1977). The following equations were used:

$$
\begin{aligned}
& \text { 1) } \text { Volume }_{\text {black spruce }}=\frac{0.0309 \mathrm{dbh}^{1.7527} \times \text { height }^{1.0014}}{0.406} \\
& \text { 2) } \text { Volume }_{\text {jack pine }}=\frac{0.0199 \mathrm{dbh}^{1.6883} \times \text { height }^{1.2456}}{0.421} \\
& \text { 3) } \text { Volume }_{\text {tamarack }}=\frac{0.0276 \mathrm{dbh}^{1.6724} \times \text { height }^{1.1443}}{0.549}
\end{aligned}
$$




\section{Example of one replicate}



Fig. 1. Schematic representation (not to scale) of one replicate block established on a Kalmia-dominated site. Each block is divided into two main plots, one of which was randomly selected to receive mechanical scarification (S1) before plantation while the other was left unscarified (SO). Each main plot comprises four 30-m $\times 30-\mathrm{m}$ subplots to which we randomly attributed one of four factorial combinations of herbicide-fertilization treatments (HOFO = no herbicide, no fertilization; HOF1 = no herbicide, with fertilization; H1FO = with herbicide, no fertilization; H1F1 = with herbicide, with fertilization). The original design included two supplemental combinations (with and without micronutrients added to NPK fertilizer) that were not considered in the present study. Subplots each contain three 10-m $\times$ 30-m sub-subplots planted with either black spruce (diamonds), jack pine (circles) or tamarack (triangles) seedlings at a 2-m $\times 2$-m spacing in 1990 (original density of $\sim 150$ seedlings/sub-subplot, later thinned to 75 seedlings/sub-subplot). In the present study, the first rows in all directions were used as buffers (dark symbols); only seedlings in the central rows (open symbols) were measured, up to 14 seedlings in each sub-subplot.

Where: Volume black spruce $_{\text {Volume }}$ jack pine and Volume tamarack $=$ stem volume without bark $\left(\mathrm{dm}^{3}\right)$, $d b h=$ tree diameter at breast height at age $25-\mathrm{y}(\mathrm{cm})$, height $=$ tree height at age $25-\mathrm{y}(\mathrm{m})$.

\section{Statistical analyses}

We used $\alpha=0.05$ as a threshold for significance for all analyses. Treatment and species main and interaction effects after 25 years (Objective 1) were evaluated by submitting tree height, dbh and estimated volume after 25 years to analyses of variance (ANOVAs) using linear mixed-effects models based on the experimental design (Fig. 1) with the function lme of package $n l m e$ in R v.3.3.2 (Pinheiro et al. 2016, R Core Team 2016,); scarification, combinations of herbicide-fertilization, species and their interactions were considered as fixed effects, and blocks and interactions involving blocks were included as random effects. We compared treatment means using Tukey's honest significant difference (HSD) tests when F-values from the ANOVAs were significant.

We compared estimated increases in time for the height of trees in control plots to reach those of trees in treated plots (Objective 2) using mean height data from the $15^{\text {th }}$ and $25^{\text {th }}$ growing seasons to calculate the number of years it would take trees in the respective control plots of the scarification and herbicide-fertilization treatments (i.e., the S0 and H0F0 treatments) to reach the same height as those in the scarified (S1) or every combination of herbicide-fertilization ( $\mathrm{H} 0 \mathrm{~F} 1$, H1F0, H1F1) treatments based on their mean growth rate over the past 10 years (Johansson et al. 2013). Calculations of increased rotation length were conducted at the sub-subplot level and were based on the ratio of the difference in mean height between each scarification or herbicide-fertilization treatments and their respective control to mean annual height increment in control treatments over the past 10 years ${ }^{4}$. For scarification, years of increased rotation length for non-scarified plots (S0) compared to scarified plots (S1) were calculated separately for black spruce, jack pine, and tamarack as:

4) $I R L=\frac{\text { height } 2014_{S 1}-\text { height } 2014_{S 0}}{\left(\text { height } 2014_{S 0}-\text { height } 2004_{S 0}\right) / 10}$

Where: $I R L=$ increase in rotation length (years), Height $2014=$ mean tree height at age 25-y (m) in scarified (S1) or non-scarified (S0) plots, Height $2004=$ mean tree height at age 15-y (m) in S0 plots.

For herbicide-fertilization treatment combinations, increase in rotation length of the control treatment (i.e., nonherbicide-non-fertilized plots) was also compared to silvicultural treatments (i.e. herbicide-non-fertilized plots, non-herbicide-fertilized plots and herbicide-fertilized plots) separately for each species:

\footnotetext{
${ }^{4}$ See supplementary Fig. S1 for a graphical representation.
} 
5) $I R L=\frac{\text { height } 2014_{H 0 F 1} \text { or } H 1 F 0 \text { or } H 1 F 1}{- \text { height } 2014_{H O F 0}}$

Where: $I R L=$ increase in rotation length (years), Height $2014=$ mean tree height at age 25-y (m) in herbicide-non-fertilized (H1F0), non-herbicidefertilized (H0F1), herbicide-fertilized plots (H1F1) and non-herbicide-non-fertilized (HOF0) plots, Height $2004=$ mean tree height at age 15-y $(\mathrm{m})$ in HOF0 plots.

Values of increase in rotation length were submitted to ANOVAs using the function lme of R. The analysis of increase in control compared to scarification (relative to non-scarified conditions) included species as a fixed effect, and block plus interaction with block as random effects. The analysis of increase in control (non-herbicide-non-fertilized) conditions relative to the three herbicide-fertilization combinations included species, herbicide-fertilization, and their interaction as fixed effects, and block plus all interactions with block as random effects.

\section{Results}

Total height, diameter at breast height and volume

Scarification interacted with species to influence 25 -year total height of planted conifers (Table 1). Scarification significantly increased black spruce and jack pine heights compared to non-scarified conditions $(p \leq 0.043)$ but its effect was not significant for tamarack ( $p=0.561$; Fig. 2a). Black spruce was significantly shorter than jack pine in both non-scarified and scarified plots $(p<0.001)$. Jack pine was shorter than tamarack in both non-scarified and scarified conditions $(p<$ 0.001 ). The herbicide-fertilization treatment had a significant effect on heights, independent of species (Table 1). Trees planted in plots that were treated with herbicide were $27 \%$ taller than ones planted in control plots $(p<0.001$; Fig. $2 b)$; however, fertilization alone did not significantly increase tree heights compared to control conditions $(p=0.452)$.

The scarification and herbicide-fertilization effects on diameter at breast height varied among species (Table 1). Black spruce diameters were significantly greater in scarified plots compared to non-scarified plots $(p=0.031)$, whereas jack pine and tamarack diameters did not respond significantly to scarification ( $p \geq 0.198$; Fig. 2 c). Diameters of jack pine and tamarack were not significantly different from each other in non-scarified plots $(p=0.977)$, but differed significantly in scarified plots $(p<0.001)$.

The combination of herbicide and fertilization resulted in significantly greater tree diameters compared to control conditions ( $p \leq 0.001)$, but the amplitude of the effect varied among species (Fig. 2d): black spruce dbh doubled in herbicide-fertilized plots compared to control plots, whereas jack pine and tamarack dbh increased by $31 \%$ and $28 \%$, respectively. Diameters of black spruce in herbicide-fertilized treatments did not differ from that of jack pine or tamarack in the control or fertilized-only treatments $(p \geq 0.059)$.

Despite a significant Scarification $\times$ Species interaction (Table 1), multiple comparison tests revealed that estimated individual tree volume did not differ significantly between non-scarified and scarified plots for all species ( $p \geq 0.057$; Fig. $2 e)$. Black spruce volumes were significantly less than jack pine and tamarack volumes in both the scarified and nonscarified plots $(p<0.001)$; jack pine and tamarack volumes were equivalent in these treatments $(p \geq 0.05)$. The scarification and herbicide-fertilization effects on volume were similar among species, but its amplitude varied from one to the other (Table 1; Fig. 2f). For all species, fertilization alone resulted in individual tree volumes similar to those found in control plots $(p \geq 0.674)$. In all cases, trees planted in herbicide-fertilized plots had greater volume than trees planted in control or fertilized-only plots $(p \leq 0.021)$. The volumes of black spruce in herbicide-fertilized plots were similar to those of jack pine and tamarack in control conditions $(p \geq 0.159)$.

\section{Increases in rotation length}

Depending on the species, increases in rotation length of one year (tamarack) to more than five years (black spruce) would be required for trees in non-scarified control plots to reach heights comparable to those which trees in scarified plots reached in 25 years (Table 2; Fig. 3a). Increases in rotation length of trees in control treatments ( $\mathrm{H} 0 \mathrm{~F} 0)$ to reach heights of those in herbicide alone, or combinations of herbicide and fertilization treatments, were also significant; as for scarification, the increased rotation length ( $>6$ years) was highest for black spruce whereas jack pine and tamarack did not differ significantly (Table 2; Fig. 3b).

Table 1. ANOVA summary for conifer dimensions 25 years after planting on a Kalmia-dominated site after various combinations of silvicultural treatments.

\begin{tabular}{|c|c|c|c|c|c|c|c|c|}
\hline \multirow[b]{2}{*}{ Effect (fixed) } & \multirow[b]{2}{*}{ num } & \multirow[b]{2}{*}{ den } & \multicolumn{2}{|c|}{ Height } & \multicolumn{2}{|c|}{ DBH } & \multicolumn{2}{|c|}{ Volume } \\
\hline & & & F Value & $\operatorname{Pr}>F$ & F Value & $\operatorname{Pr}>F$ & F Value & $\operatorname{Pr}>F$ \\
\hline Scarification (S) & 1 & 3 & 48.2 & 0.006 & 17.1 & 0.026 & 17.7 & 0.025 \\
\hline Herbicide-Fertilization (HF) & 3 & 18 & 33.9 & $<0.001$ & 45.8 & $<0.001$ & 36.0 & $<0.001$ \\
\hline $\mathrm{S} \times \mathrm{HF}$ & 3 & 18 & 2.3 & 0.115 & 1.9 & 0.173 & 1.1 & 0.383 \\
\hline Species (SP) & 2 & 48 & 710.8 & $<0.001$ & 374.4 & $<0.001$ & 254.3 & $<0.001$ \\
\hline$S \times S P$ & 2 & 48 & 7.3 & 0.002 & 21.7 & $<0.001$ & 10.1 & $<0.001$ \\
\hline $\mathrm{HF} \times \mathrm{SP}$ & 6 & 48 & 2.1 & 0.067 & 4.2 & 0.002 & 5.5 & $<0.001$ \\
\hline $\mathrm{S} \times \mathrm{HF} \times \mathrm{SP}$ & 6 & 48 & 0.5 & 0.779 & 0.9 & 0.533 & 0.795 & 0.578 \\
\hline
\end{tabular}

num $=$ numerator degrees of freedom, den = denominator degrees of freedom, DBH = diameter at breast height. Scarification treatment included two levels (scarified, non-scarified). Herbicide-fertilization treatment included four levels (no herbicide, no fertilization; no herbicide, with fertilization; with herbicide, no fertilization; with herbicide, with fertilization). Species treatment included three levels (black spruce, jack pine, tamarack). 
a)

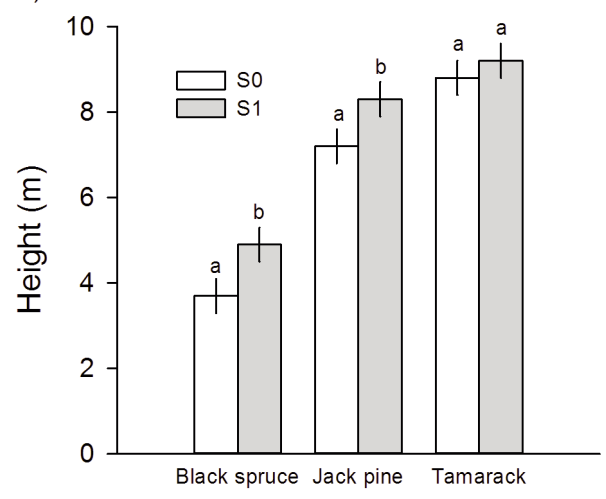

c)

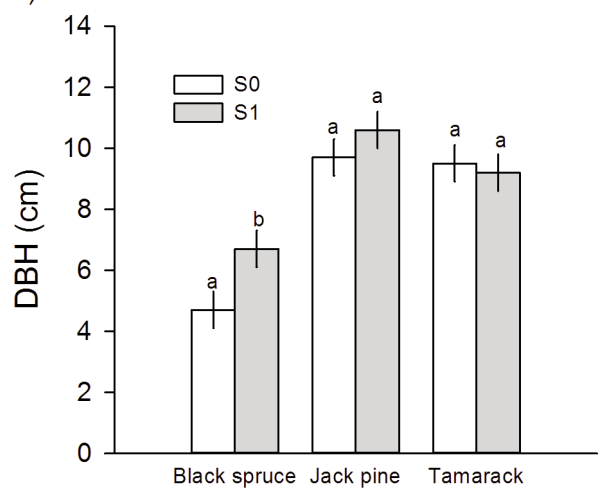

e)



b)

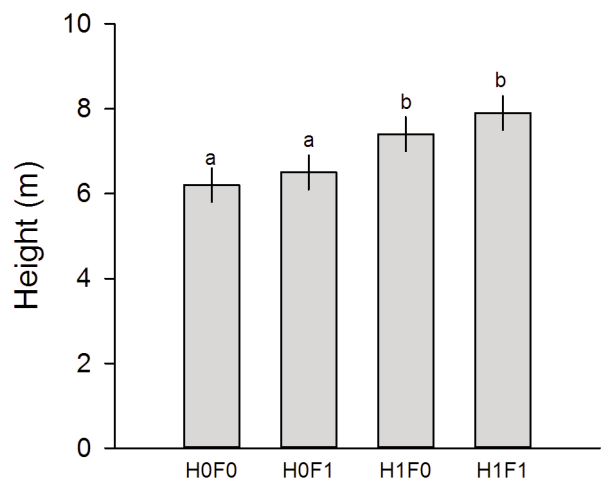

d)



f)

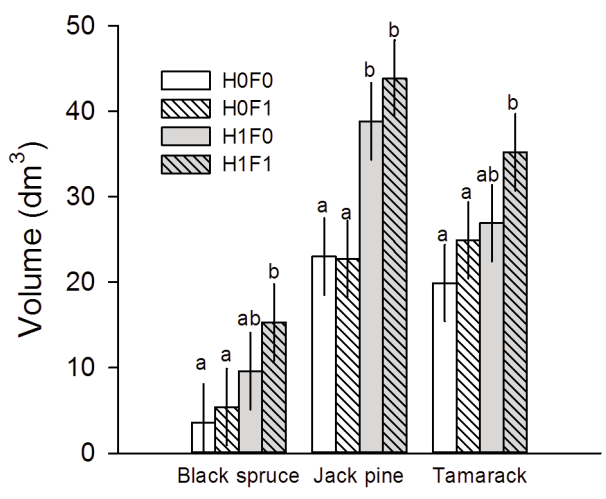

Fig. 2. Height (a,b), DBH (diameter at breast height; $\mathbf{c}, \mathbf{d}$ ) and volume (e,f) of black spruce, jack pine and tamarack trees 25 years after planting and various combinations of silvicultural treatments. Bars with the same letter are not significantly different at $\alpha=0.05$ (Tukey's HSD test). In (a), (c), (d), (e) and (f), multiple comparison results are shown by species only for clarity convenience. SO = no scarification; S1 = with scarification; HOFO = no herbicide, no fertilization; HOF1 = no herbicide, with fertilization; H1FO = with herbicide, no fertilization; H1F1 = with herbicide, with fertilization. Data presented as means \pm 2 standard errors of the mean. See Table 1 for ANOVA results.

\section{Discussion}

We predicted that there would be significant interactions between silvicultural treatments and planted species that would affect height, diameter and stem volume after 25 growing seasons. Our results confirmed this: the effects of scarification and herbicide-fertilization were not consistent among species. For example, black spruce was the most responsive species to soil scarification in relative terms for both height and diameter growth, but 25-year diameters at breast height of jack pine and tamarack did not significantly increase compared to non-scarified conditions, while diameter of black spruce increased by $43 \%$. These results are in line with earlier assessments conducted on this experimental site which showed that growth of tamarack and jack pine was no longer 
Table 2. ANOVA summary for estimated increase in rotation length for untreated trees compared to those associated with silviculture using either scarification (a) or combinations of herbicide-fertilization treatments (b), based on time until trees in control plots reach the height at age 25-y of trees in silvicultural treatment plots.

\begin{tabular}{lcccc}
\hline Effect (fixed) & num & den & F Value & Pr $>$ F \\
\hline (a) Increase in rotation length relative & to scarification \\
Species (SP) & 2 & 6 & 34.3 & $<0.001$ \\
\multicolumn{5}{l}{} \\
(b) Increase in rotation length relative & to herbicide-fertilization \\
Herbicide-Fertilization (HF) & 2 & 6 & 14.3 & 0.005 \\
$\mathrm{SP}$ & 2 & 18 & 13.1 & $<0.001$ \\
$\mathrm{HF} \times \mathrm{SP}$ & 4 & 18 & 1.4 & 0.285 \\
\hline
\end{tabular}

num $=$ numerator degrees of freedom, den = denominator degrees of freedom. In (a), increase in rotation length was calculated for unscarified plots in reference to the scarified plots for each species (black spruce, jack pine, tamarack). In (b), increase in rotation length was calculated for non-herbicided-non-fertilized plots in reference to non-herbicided-fertilized plot, herbicided-non-fertilized plots and herbicided-fertilized plots for each species.

influenced by scarification 15 years post-treatment, while black spruce was still responding significantly to this treatment (Thiffault et al. 2010). Although the scarification effect was significant for black spruce and jack pine heights and black spruce diameters, variability around the calculated volume values was too great to detect any scarification effect on this integrative variable, despite a trend towards bigger trees in scarified plots compared to unscarified plots.

The lack of consistent growth responses to silvicultural treatments among the conifers studied is likely a reflection of key differences in species autecology; for example, pines and larches have a high potential rate of $\mathrm{N}$ uptake and retranslocation efficiency compared to spruce (Reich et al. 1998b, Bothwell et al. 2001). These functional differences might render jack pine and tamarack less vulnerable than black spruce to Kalmia interference through nutritional processes, hence limiting the potential for improved growth of these species from treatments such as creating Kalmia-free microsites through scarification, reducing competition for nutrients through herbicide application, or providing nutrients through fertilization. However, no mechanistic study has yet been conducted to elucidate Kalmia interactions with conifer species other than black spruce, and these hypotheses should be tested empirically.

Species-specific responses to scarification and herbicidefertilization treatments might also be related to differences in rooting habits among the three conifers. Black spruce roots spread laterally mostly through the organic horizon (Viereck and Johnston 1990), which can be heavily colonized by Kalmia roots and rhizomes (Mallik 1993). In contrast, tamarack roots preferentially explore the mineral soil at depths of 30-61 cm (Johnston 1990) and jack pine has a robust tap root with a lateral root system concentrated at depths of 15-25 cm (Rudolph and Laidly 1990). Soil disturbance created by scarification followed by planting in microsites characterized by exposed mineral soil (the trench-berm interface) may have forced black spruce root systems to become established in soil microsites less influenced by Kalmia than the undisturbed organic rooting zones available to trees growing in control plots. This might explain the significant growth increases measured for spruce in scarified plots compared to the other species studied that naturally establish the bulk of their root systems in Kalmia-free soil layers (Plourde et al. 2009).

From a forest management perspective, the effects of silviculture on growth can be interpreted as being equivalent to a potential reduction in the rotation length needed to achieve specific production objectives (Richardson et al. 2006, Johansson et al. 2013). Our results confirm that not applying common stand establishment treatments could lead to an increase in rotation of over six years on Kalmia-dominated sites in northeastern Canada. We base this on the estimated time taken for trees in untreated control plots to attain the height of trees in treated plots 25-years after planting; we also make the conservative assumption that growth rates from this height onwards will be the same for trees in treated and untreated plots. (The differences by the end of rotation of trees in silviculturally treated plots will be greater than currently estimated if annual growth rates are still divergent after trees in control plots reach the 25-year height of trees in treated plots.) Analyses conducted on diameter at breast height confirmed the same trend, with increases of over eight years for this variable if stand establishment treatments are not applied ${ }^{5}$. Accelerated growth of planted conifers is not only beneficial in terms of wood productivity; the resultant reduced cover of Kalmia because of canopy closure has been shown to induce a positive feedback loop between conifer size and fertility of the organic soil horizon (Moroni et al. 2009). Indeed, enhanced conifer growth produces more labile coniferous litter which in turn increasingly influences nutrient cycling with a cascading positive effect on soil fertility that was previously affected by Kalmia litter rich in tannins (Joanisse et al. 2008). As soil nutrient supply increases, conifer growth is further enhanced, thus perpetuating this positive feedback cycle until factors other than Kalmia come to limit site index (Moroni et al. 2009).

We predicted that increased rotation length for control trees to reach heights comparable to those of silviculturally treated trees would be species-specific and of a greater magnitude for the slow-growing black spruce than for the fastgrowing jack pine and tamarack. Our results support this prediction and the lengthening of rotation lengths for the control compared to silvicultural treatments were two to three times greater for black spruce than for the two fast-growing species. We estimate that planting black spruce in control instead of scarified plots would lead to a $20 \%$ increase in time to attain heights achieved in 25 years in the study; the increase in time was $26 \%$ for diameter at breast height over the same period. Planting black spruce after soil scarification thus has the potential to significantly reduce rotation age (estimated at 70 years for this species on sites similar to the one we studied).

\section{Management implications}

Overall, our results illustrate the need to take species autecology into account when predicting productivity gains associated with early silviculture, and provide managers with guidance for successful reforestation of ericaceous-dominated sites in boreal ecosystems similar to the one we studied in central Newfoundland. Tamarack and jack pine achieved overall superior growth over 25 years compared to black 
a)

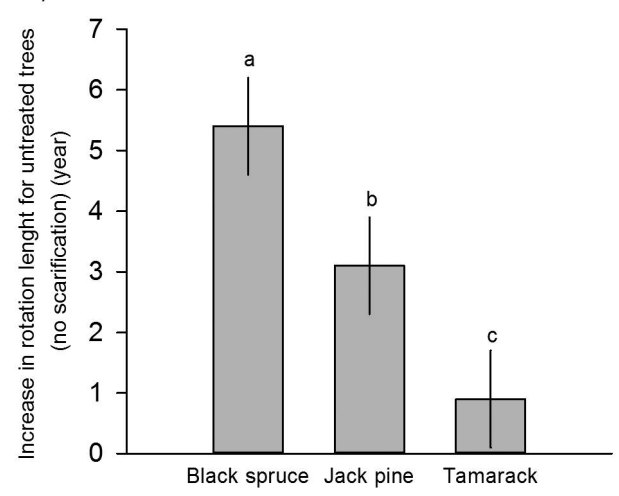

b)

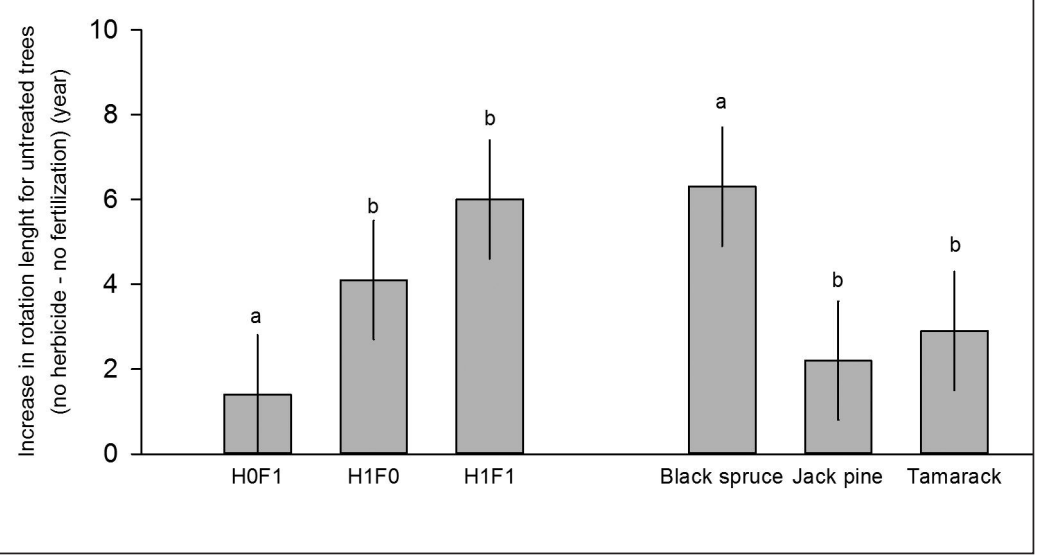

Fig. 3. Estimated increase in rotation length for untreated trees compared to those associated with silvicultural treatments of either scarification (a) or combinations of herbicide-fertilization treatments (b), based on time until trees in control plots reach the height at age 25-y of trees in silvicultural treatment plots. In (a), increase in rotation length (in years) for non-scarified plots (SO) was compared with scarified plots (S1) for black spruce, jack pine and tamarack. In (b), increase in rotation length for trees in non-herbicide-non-fertilized plots (HOFO) was compared with that for trees in herbicide-non-fertilized plots (H1FO), non-herbicide-fertilized plots (HOF1) and herbicide-fertilized plots (H1F1) for each tree species. Bars with the same letter are not significantly different at $\alpha=0.05$ (Tukey's HSD test). For (b), multiple comparison results are shown separately for the herbicide-fertilization and species treatments. Data presented as means \pm 2 standard errors of the mean. See Table 2 for ANOVA results.

spruce, a difference that is to be expected between shadeintolerant species with high potential rates of resource capture and a shade-tolerant species adapted to low-resource environments (Reich et al. 1998a). Our results support development of reforestation strategies for these sites that match species and treatment choices to achieve production objectives (Savill et al. 1997). One factor that we did not study, however, is the interaction between treatments and soil characteristics. The effects of humus manipulation on conifer establishment has been shown to vary with site variables such as texture and drainage (Béland et al. 2003); inferences from our results should thus be restricted to sites with similar well- drained, medium-textured soil as found on our study site. Our study also lacks assessment of the mechanisms responsible for the growth response (or lack thereof) to treatments 25 years after their application; past research suggests that reduced competition for nutrients and water (e.g., Thiffault et al. 2004), and increased soil nutrient availability, temperature and moisture (Thiffault and Jobidon 2006) might be involved, although water restriction is less likely because of the high precipitation regime in the study region.

Black spruce showed consistently greater responses to silvicultural treatments than the other species studied, and applying one of the most intensive treatment scenarios $(\mathrm{H} 1 \mathrm{~F} 1)$ resulted in tree dimensions at 25 years that were equivalent to those achieved by planting jack pine or tamarack in untreated plots. Moreover, spruce species can exhibit slow growth during the first few decades following establishment, but can eventually overtake other species in volume by rotation age (Eis et al. 1982). Considering that market value for spruce is usually higher than for pine or tamarack ${ }^{6}$, cost-benefit analyses could be useful for evaluating which species and treatment choices could be used to reach production objectives.

Our results also illustrate how mechanical site preparation can result in similar growth to that obtained using chemical herbicides or fertilizers on boreal sites, demonstrating that it can be applied where legislation or certification incentives limit or prevent the use of chemicals in forest management (e.g., Thiffault and Roy 2011). For example, using the site index equation of Prégent et al. (1996) for planted black spruce (which is based on the 200 tallest trees $\times \mathrm{ha}^{-1}$ ), we estimate that scarification allowed a better expression of site index for this species (7.6 $\mathrm{m}$ at age 25 -years) than either fertilization $(5.9 \mathrm{~m})$, herbicide $(6.4$ $\mathrm{m})$ or a combination of both $(6.5 \mathrm{~m})$. Although these values are in the lower half of the production tables for black spruce because of the inherent low fertility of these boreal Kalmia-dominated sites, the findings illustrate the potential of silviculture for increasing volume production and carbon sequestration. For areas where the use of either intensive mechanical soil preparation or chemical treatments raises ecological or social concerns, efforts should be pursued to further develop alternative methods that favour conifer establishment and growth (e.g., Mallik and Kravchenko 2016).

\footnotetext{
${ }^{6}$ Bureau de mise en marché de bois, Ministère des Forêts, de la Faune et des Parcs du Québec (https://bmmb.gouv.qc.ca/publications-et-reglements/tarification-forestiere/)
} 


\section{Acknowledgements}

We thank L. Price, S. Evans, S. Pelley, and R. Pretty for helping take the $15^{\text {th }}$-year measurements, and K. O'Reilly, W. Lane and J. Vokey for contributing to the $25^{\text {th }}$-year field assessment. Abitibi-Price, its successors and the Forest Service of Newfoundland and Labrador were instrumental in the establishment of the field trial, and for maintaining access to the study site over the years. We are further indebted to V. Chaffey and B. Pike (Canadian Forest Service) who contributed to the establishment, maintenance and measurement of the trial, and to J. DeBois and I. Auger for statistical advice. We extend our thanks to an Associate Editor of the journal and two anonymous reviewers who provided constructive advice on an earlier version of the manuscript, and to C. Ward for his contribution in calculating tree volume results. Use of trade, firm, or corporation names is for information only and does not constitute endorsement by the Ministère des Forêts, de la Faune et des Parcs du Québec, the Canadian Forest Service, or the Forest Service of Newfoundland and Labrador.

\section{References}

Béland, M., Y. Bergeron and R. Zarnovican. 2003. Harvest treatment, scarification and competing vegetation affect jack pine establishment on three soil types of the boreal mixed wood of northwestern Quebec. For. Ecol. Manage. 174(1-3): 477-493. doi:10.1016/ S0378-1127(02)00073-7.

Blevins, L.L., C.E. Prescott and A. Van Niejenhuis. 2006. The roles of nitrogen and phosphorus in increasing productivity of western hemlock and western redcedar plantations on northern Vancouver Island. For. Ecol. Manage. 234(1-3): 116-122. doi:10.1016/j.foreco. 2006.06.029.

Bothwell, K.S., C.E. Prescott and M.D. Jones. 2001. Factors contributing to the superior growth and $\mathrm{N}$ nutrition of 11-year-old lodgepole pine compared with Sitka spruce on an N-poor cedarhemlock cutover. Can. J. For. Res. 31(7): 1272-1279. doi:10.1139/ x01-056.

Brais, S., N. Bélanger and T. Guillemette. 2015. Wood ash and N fertilization in the Canadian boreal forest: Soil properties and response of jack pine and black spruce. For. Ecol. Manage. 348: 1-14. doi:10.1016/j.foreco.2015.03.021.

Brand, D.G. 1991. The establishment of boreal and sub-boreal conifer plantations: An integrated analysis of environmental conditions and seedling growth. For. Sci. 37(1): 68-100.

De Grandpré, L., Y. Bergeron, N.J. Fenton, T. Nguyen, C. Boudreault and P. Grondin. 2014. Composition and dynamics of the understory vegetation in the boreal forests of Québec. In: Gilliam, F.S. (ed). The Herbaceous Layer in Forests of Eastern North America, 2nd edition. pp. 294-318. Oxford University Press, New York, NY.

de Montigny, L.E. and G.F. Weetman. 1990. The effects of ericaceous plants on forest productivity. In: Titus, B.D., M.B. Lavigne, P.F. Newton and W.J. Meades (eds.). The Silvics and Ecology of Boreal Spruce. pp. 83-90. Canadian Forest Service, Forestry Canada, St. John's, Newfoundland.

Eis, S., D. Craigdallie and C. Simmons. 1982. Growth of lodgepole pine and white spruce in the central interior of British Columbia. Can. J. For. Res. 12(3): 567-575. doi:10.1139/x82-088.

Environment Canada. 2010. Canadian Climate Normals 19812010 Station Data. Available from http://climate.weather.gc.ca/climate_normals/index_e.html [accessed 26 August 2016].

Holmes, G.D. and D.A. Cousins. 1960. Application of fertilizers to checked plantations. Forestry 33(1): 54-73. doi:10.1093/forestry/ 33.1.54.
Joanisse, G.D., R.L. Bradley and C.M. Preston. 2008. Do late-successional tannin-rich plant communities occurring on highly acidic soils increase the DON/DIN ratio? Biol. Fertility Soils 44(6): 903-907. doi:10.1007/s00374-008-0297-z.

Jessome, A.P. 1977. Strength and related properties of woods grown in Canada. Eastern Forest Products Laboratory. Forestry Technical Report 21. Ottawa, ON.

Johansson, K., U. Nilsson and G. Örlander. 2013. A comparison of long-term effects of scarification methods on the establishment of Norway spruce. Forestry 86(1): 91-98. doi:10.1093/forestry/cps062. Johnston, W.F. 1990. Larix laricina (Du Roi) K. Koch. Tamarack. In: R.H. Burns and B.H. Honkala (eds). Silvics of North America. Vol. 1. Conifers. U.S. Dep. Agric. For. Serv. Handbook 654.

Kranabetter, J.M., S. Dube and E.B. Lilles. 2017. An investigation into the contrasting growth response of lodgepole pine and white spruce to harvest-related soil disturbance. Can. J. For. Res. 47(3): 340-348. doi:10.1139/cjfr-2016-0386.

Lambert, M.C., C.H. Ung and F. Raulier. 2005. Canadian national tree aboveground biomass equations. Can. J. For. Res. 35(8): 1996-2018. doi:10.1139/x05-112.

LeBel, P., N. Thiffault and R.L. Bradley. 2008. Kalmia removal increases nutrient supply and growth of black spruce seedlings: An effect fertilizer cannot emulate. For. Ecol. Manage. 256(10): 1780-1784. doi:10.1016/j.foreco.2008.02.050.

Lorimer, C.G., J.W. Chapman and W.D. Lambert. 1994. Tall understorey vegetation as a factor in the poor development of oak seedlings beneath mature stands. J. Ecol. 82(2): 227-237.

Mallik, A.U. 1993. Ecology of a forest weed of Newfoundland: Vegetative regeneration strategy of Kalmia angustifolia. Can. J. Bot. 71(1): 161-166. doi:10.1139/b93-018.

Mallik, A.U. 2003. Conifer regeneration problems in boreal and temperate forests with ericaceous understory: Role of disturbance, seedbed limitation, and keystone species change. Crit. Rev. Plant Sci. 22(3-4): 341-366. doi:10.1080/713610860.

Mallik, A. and D. Kravchenko. 2016. Black spruce (Picea mariana) restoration in Kalmia heath by scarification and microsite mulching. For. Ecol. Manage. 362: 10-19. doi:10.1016/j.foreco.2015.10.020.

Mason, E.G. 1992. Decision-support systems for establishing radiata pine plantations in the central north island of New Zealand. Ph.D. Thesis. University of Canterbury, Christchurch, New Zealand. Meades, W.J. and L. Moores. 1994. Forest site classification manual: A field guide to the Damman forest types of Newfoundland, 2nd ed. Canada-Newfoundland Forest Resource Development Agreement. FRDA Report. 003. Corner Brook, NF.

Moroni, M.T., N. Thiffault, B.D. Titus, C. Mante and F. Makeschin. 2009. Controlling Kalmia and reestablishing conifer dominance enhances soil fertility indicators in central Newfoundland, Canada. Can. J. For. Res. 39(7): 1270-1279. doi:10.1139/X09-061. Moulinier, J., S. Brais, B. Harvey and A. Koubaa. 2015. Response of boreal jack pine (Pinus banksiana Lamb.) stands to a gradient of commercial thinning intensities, with and without $\mathrm{N}$ fertilization. Forests 6(8): 2678-2702. doi:10.3390/f6082678.

Nilsson, M.-C. and D.A. Wardle. 2005. Understory vegetation as a forest ecosystem driver: Evidence from the northern Swedish boreal forest. Front. Ecol. Environ. 3(8): 421-428. doi:10.2307/3868658.

Nilsson, U. and G. Örlander. 2003. Response of newly planted Norway spruce seedlings to fertilization, irrigation and herbicide treatments. Ann. For. Sci. 60(7): 637-643. doi:10.1051/forest:2003056.

Örlander, G., P. Gemmel and J. Hunt. 1990. Site preparation: A Swedish overview. FRDA Report 105. Victoria, BC.

Périé, C. and A.D. Munson. 2000. Ten-year responses of soil quality and conifer growth to silvicultural treatment. Soil Sci. Soc. Am. J. 64(5): 1815-1826. doi:10.2136/sssaj2000.6451815x.

Perron, J.-Y. 2003. Tarif de cubage général. Volume marchand brut. Direction des inventaires forestiers, Ministère des Ressources naturelles, de la Faune et des Parcs. Québec, QC. 
Pinheiro, J., D. Bates, S. DebRoy, D. Sarkar and R Core Team. 2016. nlme: Linear and Nonlinear Mixed Effects Models.

Plourde, A., C. Krause and D. Lord. 2009. Spatial distribution, architecture, and development of the root system of Pinus banksiana Lamb. in natural and planted stands. For. Ecol. Manage. 258(9): 2143-2152. doi:10.1016/j.foreco.2009.08.016.

Prégent, G., V. Bertrand and L. Charette. 1996. Tables préliminaires de rendement pour les plantations d'Épinette noire au Québec. Ministère des Ressources naturelles, Gouvernement du Québec. Mémoire de recherche forestière 118. Québec, QC.

Prescott, C.E. and T. Sajedi. 2008. The role of salal in forest regeneration problems in coastal British Columbia: Problem or symptom? For. Chron. 84(1): 29-36. doi: 10.5558/tfc84029-1.

Prévost, M. 1992. Effets du scarifiage sur les propriétés du sol, la croissance des semis et la compétition : Revue des connaissances actuelles et perspectives de recherches au Québec. Ann. Sci. For. 49(3): 277-296. doi:10.1051/forest:19920306.

Prévost, M. and D. Dumais. 2003. Croissance et statut nutritif de marcottes, de semis naturels et de plants d'épinette noire à la suite du scarifiage : résultats de 10 ans. Can. J. For. Res. 33(1): 2097-2107. doi:10.1139/X03-130.

R Core Team. 2016. R: A language and environment for statistical computing. R Foundation for Statistical Computing, Vienna, Austria. Reich, P.B., M.G. Tjoelker, B. Walters, D. Vanderklein and C. Buschena. 1998a. Close association of RGR, leaf and root morphology, seed mass and shade tolerance in seedlings of nine boreal tree species grown in high and low light. Funct. Ecol. 12(3): 327-338. doi:10.1046/j.1365-2435.1998.00208.x.

Reich, P.B., M.B. Walters, M.G. Tjoelker, D. Vanderklein and C. Buschena. 1998b. Photosynthesis and respiration rates depend on leaf and root morphology and nitrogen concentration in nine boreal tree species differing in relative growth rate. Funct. Ecol. 12(3): 395-405. doi:10.1046/j.1365-2435.1998.00209.x.

Richardson, B., M.S. Watt, E.G. Mason and D.J. Kriticos. 2006. Advances in modelling and decision support systems for vegetation management in young forest plantations. Forestry 79(1): 29-42. doi:10.1093/forestry/cpi059.

Richardson, J. 1979. A comparison of methods of reforesting sites invaded by Kalmia angustifolia, using black spruce. Environment Canada, Forestry Service, Newfoundland Forest Research Centre. Information Report. N-X-174. St. John's, NF.

Royo, A.A. and W.P. Carson. 2006. On the formation of dense understory layers in forests worldwide: Consequences and implications for forest dynamics, biodiversity, and succession. Can. J. For. Res. 36(6): 1345-1362. doi:10.1139/X06-025.

Rudolph, T.D. and P.R. Laidly. 1990. Pinus banksiana Lamb. Jack pine. In: R.H. Burns and B.H. Honkala (eds.). Silvics of North America. Vol. 1. Conifers. U.S. Dep. Agric. For. Serv. Handbook 654.

Saucier, J.-P., K. Baldwin, P. Krestov and T. Jorgenson. 2015. Boreal Forests. In: Peh, K.S.-H., R.T. Corlett and Y. Bergeron (eds.). Routledge Handbook of Forest Ecology. pp. 7-29. Routledge, Oxford, UK.

Savill, P., J. Evans, D. Auclair and J. Falk. 1997. Plantation Silviculture in Europe. Oxford University Press, New York, NY.

Sloan, J.L. and D.F. Jacobs. 2013. Fertilization at planting influences seedling growth and vegetative competition on a post-mining boreal reclamation site. New For. 44(5): 687-701. doi:10.1007/s11056-0139378-4.

Soil Classification Working Group. 1998. The Canadian System of Soil Classification. 3rd ed. Agriculture and Agri-Food Canada. Publication 1646. Ottawa, ON.
Taylor, C.M.A. and P.M. Tabbush. 1990. Nitrogen deficiency in Sitka spruce plantations. Forestry Commission. Bulletin 89. London, UK.

Thiffault, N. and R. Jobidon. 2006. How to shift unproductive Kalmia angustifolia - Rhododendron groenlandicum heath to productive conifer plantation. Can. J. For. Res. 36(10): 2364-2376. doi:10.1139/x06-090.

Thiffault, N. and V. Roy. 2011. Living without herbicides in Québec (Canada): Historical context, current strategy, research and challenges in forest vegetation management. Eur. J. For. Res. 130(1): 117-133. doi:10.1007/s10342-010-0373-4.

Thiffault, N., B.D. Titus and A.D. Munson. 2004. Black spruce seedlings in a Kalmia-Vaccinium association: Microsite manipulation to explore interactions in the field. Can. J. For. Res. 34(8): 1657-1668. doi:10.1139/x04-046.

Thiffault, N., B.D. Titus and A.D. Munson. 2005. Silvicultural options to promote seedling establishment on Kalmia-Vacciniumdominated sites. Scand. J. For. Res. 20(2): 110-121. doi:10.1080/ 02827580510008356 .

Thiffault, N., B.D. Titus and M.T. Moroni. 2010. Silviculture and planted species interact to influence reforestation success on a Kalmia-dominated site - a 15-year study. Forest. Chron. 86(2): 234-242. doi:10.5558/tfc86234-2.

Thiffault, N., F. Hébert and R. Jobidon. 2012a. Planted Picea mariana growth and nutrition as influenced by silviculture $\times$ nursery interactions on an ericaceous-dominated site. Silva Fenn. 46(5): 667-682.

Thiffault, N., G. Picher and I. Auger. 2012b. Initial distance to Kalmia angustifolia as a predictor of planted conifer growth. New For. 43(5-6): 849-868. doi:10.1007/s11056-012-9324-x.

Thiffault, N., N. Fenton, A.D. Munson, F. Hébert, R. Fournier, O. Valeria, R. Bradley, Y. Bergeron, P. Grondin, D. Paré and G. Joanisse. 2013. Managing understory vegetation for maintaining productivity in black spruce forests: A synthesis within a multi-scale research model. Forests 4(3): 613-631. doi:10.3390/f4030613.

Titus, B.D., S.S. Sidhu and A.U. Mallik. 1995. A summary of some studies on Kalmia angustifolia L.: A problem species in Newfoundland forestry. Natural Resources Canada, Canadian Forest Service. Information Report N-X-296. St-John's, NFL.

Viereck, L.A. and W.F. Johnston. 1990. Picea mariana (Mill.) B.S.P. Black spruce. In: R.H. Burns and B.H. Honkala (eds.). Silvics of North America. Vol. 1. Conifers. U.S. Dep. Agric. For. Serv. Handbook 654 .

Wagner, R.G. and A.P. Robinson. 2006. Critical period of interspecific competition for four northern conifers: 10-year growth response and associated vegetation dynamics. Can. J. For. Res. 36(10): 2474-2485. doi:10.1139/X06-058.

Wagner, R.G., K.M. Little, B. Richardson and K. McNabb. 2005. The role of vegetation management for enhancing productivity of the world's forests. Forestry 79(1): 57-79. doi:10.1093/forestry/cpi057.

Walstad, J.D. and P.J. Kuch. 1987. Forest vegetation management for conifer production. Wiley, New York, NY.

Weatherell, J. 1953. The checking of forest trees by heather. Forestry 26(1): 37-40. doi:10.1093/forestry/26.1.37.

Zackrisson, O., G. Norberg, A. Dolling, M.-C. Nilsson and A. Jäderlund. 1997. Site preparation by steam treatment: Effects on forest vegetation control and establishment, nutrition, and growth of seeded Scots pine. Can. J. For. Res. 27(3): 315-322. doi:10.1139/x96172 . 